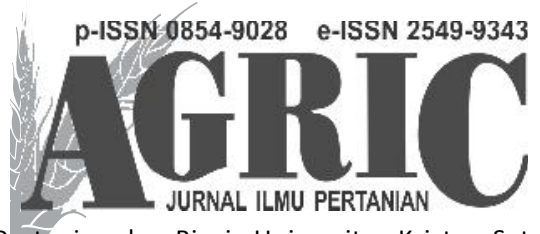

Fakultas Pertanian dan Bisnis Universitas Kristen Satya Wacana Jl. Diponegoro 52-60 SALATIGA 50711 - Telp. 0298-321212 ext 354

email: agric_fpb@yahoo.co.id, website: ejournal.uksw.edu/agric

\title{
DAMPAK KEANGGOTAAN KELOMPOK LUMBUNG PANGAN MASYARAKAT TERHADAP PENDAPATAN USAHATANI PADI DI KABUPATEN TAKALAR
}

\section{THE IMPACT OF GRANARY COMMUNITY MEMBERSHIP ON PADDY FARM INCOME IN TAKALAR}

\author{
Muh Tahir, Sri Mardiyati, dan Sitti Arwati \\ Program Studi Agribisnis Fakultas Pertanian \\ Universitas Muhammadiyah Makassar \\ sri.mardiyati@unismuh.ac.id
}

Diterima 3 Juli 2017, disetujui 14 Juli 2017

\begin{abstract}
This study aims to analyze the income of paddy farming in members and non-members of the community granary group, and to know the impact of the membership of the granary group on the income of paddy farming. This research was conducted in Bontoloe Village, Galesong Sub-District, Takalar District, South Sulawesi Province. Sampling was done by two methods, first for sample of granary member using purposive sampling method, second fornon-member of granary using simple random sampling method. So the total sample in this study were 34 farmers. Data analysis used is the analysis of different test ( $t$ test) and multiple linear regression. The results showed that the income earned by farmer members of the granary group amounted to $R p$ 9,386,227.00, while the income earned by non-member farmers in the granary group was $R p 9,175,144$.00. Differences in paddy production, revenue, and income levels between member farmers and non-members of the granary group based on t test proved not significantly different. Factors that significantly affect the income level of paddy farming are land area, paddy seed price, pesticide price, and labor wage. While the impact of membership of community granary group was not significant to the income of paddy farming. But simultaneously (land area, price of paddy seed, price of urea fertilizer, phonska fertilizer price, pesticide price, labor wage, dummy member) can affect paddy farming income of $84.99 \%$.
\end{abstract}

Keywords: granary, income, membership, paddy farming 


\begin{abstract}
ABSTRAK
Penelitian ini bertujuan untuk menganalisis pendapatan usahatani padi pada anggota dan bukan anggota kelompok lumbung masyarakat, dan untuk mengetahui dampak keanggotaan kelompok lumbung pada pendapatan beras. Penelitian ini dilakukan di Desa Bontoloe, Kecamatan Galesong, Kabupaten Takalar, Provinsi Sulawesi Selatan. Pengambilan sampel dilakukan dengan dua metode, pertama untuk sampel lobak dengan metode purposive sampling, kedua untuk anggota lumbung dengan metode simple random sampling. Jadi total sampel dalam penelitian ini adalah 34 petani. Analisis data yang digunakan adalah analisis uji beda ( $\mathrm{t}$ test) dan regresi linier berganda. Hasil penelitian menunjukkan bahwa pendapatan yang diperoleh anggota kelompok lumbung sebesar Rp 9.386.297,00, sedangkan pendapatan petani non anggota pada kelompok lumbung adalah Rp 9.175.144,00. Perbedaan dalam produksi beras, pendapatan, pendapatan dan pendapatan antara anggota kelompok tani dan anggota kelompok non kelompok berdasarkan uji t terbukti tidak berbeda nyata. Faktor yang secara signifikan mempengaruhi tingkat pendapatan usahatani padi adalah luas lahan, harga benih padi, harga pestisida, dan upah buruh. Sedangkan dampak keanggotaan kelompok lumbung masyarakat tidak signifikan terhadap pendapatan usahatani padi. Namun secara simultan (luas lahan, harga benih padi, harga pupuk urea, harga pupuk phonska, harga pestisida, upah buruh, variabel dummy) dapat mempengaruhi pendapatan usahatani padi sebesar 84,99\%.
\end{abstract}

Kata kunci: lumbung, pendapatan, keanggotaan, usahatani padi

\section{PENDAHULUAN}

Pangan sebagai kebutuhan dasar manusia sangat menentukan kelangsungan hidup rakyat.Ketidakcukupanpanganberpotensi mengguncang stabilitas sosial dan ketahanan nasional. Namun jika pangan tersedia sesuai dengan kebutuhan dan terjangkau daya beli, masyarakat akan memberi dukungan terhadap stabilitas nasional di bidang ekonomi dan politik. Oleh karenanya pangan juga merupakan barang strategis karena menjadi penentu pertahanan dan keamanan, sosial dan politik suatu negara. Tidak mengherankan jika pangan hingga hari ini tetap menjadi bagian penting kebijaksanaan ekonomi hampir semua negara (Witoro, etal.dalam Mardiyati, 2014).

Penguatan cadangan pangan masyarakat dapat ditempuh melalui pengembangan kelembagaan lumbung pangan di daerah perdesaan. Keberadaan lumbung pangan menyusut sejalan dengan kebijakan peningkatan peran Bulog dalam menjamin cadangan dan harga pangan. Namun demikian dengan relatif semakin mengecilnya peran Bulog dalam menangani cadangan pangan, keberadaan lumbung pangan kembali mendapat perhatian (Rachmat, et al. dalam Mardiyati, 2016).

Padi (beras) merupakan pangan pokok bagi masyarakat Indonesia, sehingga ketersediaannya harus senantiasa terpenuhi sepanjang waktu. Menurut Suharyanto, et al. (2014), sebagian besar petani padi sawah di Indonesia masih tergolong petani subsisten dalam arti berperan sebagai produsen sekaligus konsumen beras. Dengan demikian maka jumlah beras yang dijual ke pasar akan sangat tergantung pada surplus konsumsi rumahtangga dan harga beras serta harga barang lain yang diperlukan petani dari industri lain. Jika rumahtangga petani subsisten tersebut menjual produk beras sampai mengurangi jumlah untuk konsumsi rumah tangga agar dapat membeli barang/jasa lain yang tidakdiproduksinya maka ketahanan pangan rumahtangga akan menurun.

Menurut Irham dalam Mardiyati (2014), selama ini lumbung pangan dikenal sebagai tempat penyimpanan bahan pangan, guna mengatasi siklus produksi pangan yang 
berfluktuasi akibat musim serta untuk mengantisipasi adanya kegagalan panen yang diakibatkan bencana alam seperti serangan hama dan penyakit, banjir, kekeringan, dan lainlain. Seiring dengan kemajuan teknologi maka fungsi lumbung pangan diharapkan tidak sekedar untuk menampung cadangan pangan yang bisa dimanfaatkan untuk membantu anggota yang membutuhkan dengan suatu mekanisme lokal yang disepakati, akan tetapi lebih dari itu dapat menjadi lembaga perekonomian perdesaan yang mempunyai tugas sebagai pengolah cadangan pangan masyarakat. Lumbung pangan juga bisa digunakan dalammengendalikan harga dengan sistem tunda jual yaitu menyimpan hasil panen di lumbung pada panen raya, saat harga jatuh, kemudian gabah yang disimpan akan dijual pada saat harga stabil.

Keterlibatan dan keaktifan petani padi dalam keanggotaan kelompok lumbung pangan masyarakat diharapkan dapat mempengaruhi tingkat produktivitas usahataninya sehingga pendapatan yang diperoleh juga akan meningkat. Penelitian ini bertujuan untuk menganalispendapatan usahatani padi pada anggota dan non-anggota kelompok lumbung pangan, untuk mengetahui dampak keanggotaan kelompok lumbung pangan terhadap pendapatan usahatani padi, serta faktor-faktor yang mempengaruhinya.

\section{METODE PENELITIAN}

Penelitian ini dilaksanakan diDesa Bontoloe, Kecamatan Galesong Kabupaten Takalar, Provinsi Sulawesi Selatan. Penentuan lokasi dilakukan secara purposif, alasannya bahwa daerah ini sebagai satu-satunya wilayah di Kecamatan Galesong yang memiliki kelompok lumbung pangan masyarakat, serta menerima bantuan sosial dari program pemerintah. Pengambilan sampel dilakukan dengan dua metode, pertama untuk sampel anggota lumbung pangan menggunakan metode purposive sampling, kedua untuk non-anggota lumbung pangan menggunakan metode simple random sampling. Jadi jumlah keseluruhan sampel dalam penelitian ini sebanyak 34 orang petani. Analisis data yang digunakan yaitu analisis uji beda nyata (uji t) dan regresi linier berganda.

Untuk menghitung besarnya pendapatan usahatani padi digunakan rumus:

$$
\mathrm{I}=\mathrm{TR}-\mathrm{TC}
$$

Dimana:

I = Pendapatan usahatani padi

$\mathrm{TR}=$ Total penerimaan

$\mathrm{TC}=$ Total biaya

Untuk menganalisis perbedaan produksi, penerimaan, dan pendapatan usahatani padi antara petani anggota dan non-anggota kelompok lumbung pangan maka digunakan analisis $t$-test(Sugiyono, 2008):

$$
t=\frac{\left(\bar{x}_{1}-\bar{x}_{2}\right)}{\sqrt{\frac{s_{1}^{2}}{n_{1}}+\frac{s_{2}^{2}}{n_{2}}}}
$$

Dimana:

$\overline{\mathrm{x}}_{1}=$ rata-rata produksi/penerimaan/pendapatan untuk petani non-anggota lumbung pangan

$\overline{\mathrm{x}}_{2}=$ rata-rata produksi/penerimaan/pendapatan untuk petani anggota lumbung pangan

$\mathrm{s}_{1}{ }^{2}=$ standar deviasi produksi/penerimaan/ pendapatan untuk petani non-anggota lumbung pangan

$\mathrm{s}_{2}{ }^{2}=$ standar deviasi produksi/penerimaan/ pendapatan untuk petani anggota lumbung pangan

$\mathrm{n}_{1}=$ ukuran sampel untuk petani non-anggota lumbung pangan

$\mathrm{n}_{2}=$ ukuran sampel untuk petani anggota lumbung pangan. 
Sedangkan untuk mengetahui dampak keanggotaan kelompok lumbung pangan terhadap pendapatan usahatani padi dan faktorfaktor yang mempengaruhi tingkat pendapatan usahatani padi, maka digunakan rumus regresi linier berganda seperti berikut ini.

$$
\begin{aligned}
\ln Y= & b_{0}+b_{1} \ln X_{1}+b_{2} \ln X_{2}+b_{3} \ln X_{3}+b_{4} \ln X_{4}+ \\
& b_{5} \ln X_{5}+b_{6} \ln X_{6}+D A+e
\end{aligned}
$$

Dimana:

$\mathrm{Y}=$ Pendapatan usahatani padi (Rp)

$\mathrm{X}_{1}=$ Luas lahan (ha)

$\mathrm{X}_{2}=$ Harga benih padi $(\mathrm{Rp} / \mathrm{kg})$

$\mathrm{X}_{3}=$ Harga pupuk urea $(\mathrm{Rp} / \mathrm{kg})$

$\mathrm{X}_{4}=$ Harga pupuk phonska $(\mathrm{Rp} / \mathrm{kg})$

$\mathrm{X}_{5}=$ Harga pestisida $(\mathrm{Rp} / \mathrm{kg})$

$\mathrm{X}_{6}=$ Upah tenaga kerja $(\mathrm{Rp} / \mathrm{HOK})$

$\mathrm{DA}=$ Dummy anggota lumbung pangan

$$
\text { (D1 = anggota, D0 =non-anggota) }
$$

$\mathrm{e}=$ error term

$\mathrm{b}_{0}=$ Intersep

$\mathrm{b}_{1}-\mathrm{b}_{6}=$ Koefisien regresi

\section{HASIL DAN PEMBAHASAN}

\section{Perbedaan Pendapatan Usahatani Padi pada Petani Anggota dan Non-Anggota Kelompok Lumbung pangan}

Kebijakan pengembangan lumbung pangan masyarakat pada dasarnya diarahkan untuk: (1)mewujudkan peningkatan volume cadangan di kelompok; (2) meningkatkan kemampuan teknis anggota kelompok dalam pengelola cadangan pangan masyarakat; dan (3) meningkatkan kemampuan kelompok untuk memperoleh nilai tambah (Anonim, 2015). Dengan demikian, petani yang aktif dalam keanggotaan dan kegiatan kelompok lumbung pangan diharapkan memiliki tingkat pendapatan usahatani padi yang relatif lebih tinggi.
Pendapatan adalah selisih antara penerimaan dan semua biaya (Soekartawi,2006). Untuk mengetahui besarnya perbedaan pendapatan usahatani padi pada petani anggota dan nonanggota kelompok lumbung pangan maka dapat dilihat pada Tabel 1 berikut.

Tabel 1 Biaya dan Pendapatan Usahatani Padi per Hektar pada Petani Anggota dan Non-Anggota Kelompok Lumbung Pangan

\begin{tabular}{lrr}
\hline \multirow{2}{*}{ Uraian } & \multicolumn{2}{c}{ Nilai (Rp) } \\
\cline { 2 - 3 } & \multicolumn{1}{c}{ Anggota } & \multicolumn{1}{c}{$\begin{array}{c}\text { Non- } \\
\text { Anggota }\end{array}$} \\
\hline 1. Penerimaan & 13.999 .818 & 13.953 .606 \\
2. Total Biaya & 4.613 .591 & 3.579 .247 \\
- Biaya Variabel & 4.008 .072 & 3.021 .875 \\
- Biaya Tetap & 605.519 & 557.372 \\
3. Pendapatan & 9.386 .227 & 9.175 .144 \\
\hline Sumber: Analisis Data Primer, 2016.
\end{tabular}

Menurut Tabel 1 maka dapat dilihat bahwa pendapatan usahatani padi untuk anggota kelompok lumbung pangan relatif cenderung lebih tinggi jika dibandingkan dengan petani yang bukan anggota atau non-anggota kelompok lumbung pangan. Namun, selanjutnya apabila dilakukan uji beda nyata secara statistik atau uji t, maka perbedaan tersebut terbukti tidak signifikan. Keadaan tersebut dapat dicermati pada Tabel 2 berikut ini.

Tabel 2 Perbandingan Produksi, Penerimaan, dan Pendapatan Usahatani Padi pada Petani Anggota dan Non-Anggota Kelompok Lumbung Pangan

\begin{tabular}{lcc}
\hline \multicolumn{1}{c}{ Uraian } & ${ }^{\mathrm{t}}$ hitung & $\mathrm{t}$ tabel \\
\hline Produksi & $-0,190$ & 1,694 \\
Penerimaan & $-0,207$ & 1,694 \\
Pendapatan & $-0,043$ & 1,694 \\
\hline
\end{tabular}

Sumber : Analisis Data Primer, 2016

Pada Tabel 2 dapat dipahami bahwa berdasarkan hasil analisis uji beda atau ttest maka tingkat produksi, penerimaan, dan pendapatan usahatani padi antara petani anggota dan petani non-anggota kelompok lumbung pangan tidak terbukti ada perbedaan 
yang nyata. Hal ini berarti bahwa keanggotaan petani dalam kegiatan pengembangan kelompok lumbung pangan masyarakat secara keseluruhan belum berpengaruh terhadap peningkatan pendapatan usahatani padi.

\section{Faktor-faktor yang Mempengaruhi Pendapatan Usahatani Padi dan Dampak Keanggotaan Kelompok Lumbung Pangan}

Desa Bontoloe Kecamatan Galesong merupakan desa yang mendapatkan bantuan program pemerintah berupa pengembangan kelompok lumbung pangan (bernama Lumbung Pangan Panrannuanta)yang dapat dimanfaatkan oleh petani, baik untuk penyimpanan atau tunda jual gabah ataupun menjual gabah ke kelompok lumbung pangan dengan harga yang lebih baik dari pedagang pengumpul maupun meminjam modal untuk memulai usahataninya.Meski mempunyai manfaat yang begitu besar masyarakat Desa Bontoloe hanya sebagian kecil saja yang tergabung dalam keanggotaan lumbung pangan. Hal ini disebabkan karena tidak banyak yang tahu akan keberadaan lumbung pangan itu sendiri. Sosialisasi yang kurang terhadap masyarakat merupakan pemicu utama dari ketidaktahuan akan manfaat, fungsi dan tujuan dari lumbung pangan begitupun dengan petani yang tergabung.

Meskipun kelompok lumbung pangan ini memberikan banyak manfaat bagi para anggotanya, namun lumbung pangan juga mempunyai kekurangan dalam pengelolaannya yaitu bagi petani non anggota kelompok lumbung pangan tidak dapat meminjam modal atau pangan lainnya ke lumbung untuk kepentingan usahatani atau lainnya.Oleh karena itu maka bagi petani anggotakelompok lumbung pangan diharapkan keaktifannya dapat berdampak pada peningkatan pendapatan usahataninya. Untuk mengetahui pengaruh tersebut maka dapat dilihat pada Tabel 3.
Tabel 3 Faktor-faktor yang Berpengaruh terhadap Pendapatan Usahatani Padi pada Petani Anggota dan Non-Anggota Lumbung Pangan

\begin{tabular}{|c|c|c|c|}
\hline Variabel & Koefisien & t_stat & Prob. \\
\hline Konstanta & 19,406 & 4,347 & 0,000 \\
\hline Luas lahan & $0,843^{* * *}$ & 16,42 & 0,000 \\
\hline Harga benih & $0,212^{*}$ & 1,827 & 0,079 \\
\hline Harga urea & $-0,066^{\mathrm{ns}}$ & $-0,159$ & 0,875 \\
\hline Harga phonska & $0,129^{\mathrm{ns}}$ & 0,377 & 0,709 \\
\hline Harga pestisida & $-0,066^{*}$ & $-1,997$ & 0,056 \\
\hline Upah tenagakerja & $-0,472^{* * *}$ & $-5,646$ & 0,000 \\
\hline Dummyanggota & $-0,029^{n s}$ & $-0,801$ & 0,431 \\
\hline R-Square & \multicolumn{2}{|c|}{$=0,849888$} & \\
\hline F-Statistik & \multicolumn{2}{|c|}{$=21,02918$} & \\
\hline \multicolumn{4}{|c|}{$\begin{array}{l}\text { Prob }(\text { F-Statistik })=0,000000 * * * \\
* * *) \text { : signifikan }(\alpha=1 \%)\end{array}$} \\
\hline \multicolumn{4}{|c|}{$* *):$ signifikan $(\alpha=5 \%)$} \\
\hline \multicolumn{4}{|c|}{$*)$ : signifikan $(\alpha=10 \%)$} \\
\hline \multicolumn{4}{|c|}{ ns) : non signifikan } \\
\hline
\end{tabular}

Sumber: Analisis Data Primer, 2016

Berdasarkan hasil analisis regresi yang tertera pada Tabel 3 menunjukkan bahwa secara keseluruhan (uji F atau over all) maka variabel luas lahan, harga benih padi, harga pupuk urea, harga pupuk phonska, harga pestisida, upah tenaga kerja, dan keanggotaan kelompok lumbung pungan dapat mempengaruhi tingkat pendapatan usahatani padi sebesar 84,99 persen, artinya 15,01 persen disebabkan oleh faktor-faktor lain yang tidak diprediksi. Namun demikian apabila dianalisis secara parsial (uji t) maka faktor-faktor yang berpengaruh secara nyata terhadap tingkat pendapatan usahatani padi adalah luas lahan, harga benih padi, harga pestisida, dan upah tenaga kerja.

Luas lahan terbukti secara signifikan, dengan tingkat kepercayaan 99 persen, berpengaruh positif terhadap tingkat pendapatan usahatani padi sebesar 0,843. Artinya bahwa apabila luas lahan ditambah 1 (satu) persen maka pendapatan usahatani padi akan meningkat sebesar 0,843 persen. Sehingga dapat disimpulkan bahwa semakin luas lahan yang diusahakan petani padi maka akan semakin tinggi pendapatan usahataninya. 
Harga benih padi secara signifikan berpengaruh positif terhadap peningkatan pendapatan usahatani padi sebesar 0,212 persen, dengan tingkat kepercayaan 90 persen (tingkat kesalahan atau $\alpha=10 \%$ ). Hal ini berarti apabila harga benih padi naik sebesar satu persen maka pendapatan usahataninya meningkat sebesar 0,212 persen. Sebenarnya hal ini cukup kontradiktif secara teoritis, tetapi alasannya adalah penggunaan benih padi yang lebih mahal akan meningkatkan produktivitas tanaman padi, karena semakin mahal benih padi biasanya semakin berkualitas benihnya.

Harga pestisida secara signifikan berpengaruh negatif terhadap tingkat pendapatan usahatani padi sebesar -0,066 pada tingkat kepercayaan 90 persen. Artinya apabila harga pestisida naik sebesar satu persen maka pendapatan usahatani padi akan menurun sebesar 0,066 persen. Dengan demikian, semakin mahal harga pestisida maka akan semakin menurun tingkat pendapatan usahatani padi.

Upah tenaga kerja secara signifikan memiliki pengaruh negatif yang paling dominan terhadap tingkat pendapatan usahatani padi yakni sebesar $-0,472$, dengan tingkat kepercayaan 99 persen. Sehingga jika upah tenaga kerja naik satu persen maka pendapatan usahatani padi akan menurun sebesar 0,472 persen, dengan kata lain apabila upah tenaga kerja naik 100 persen maka pendapatan usahatani padi turun sebesar 47,2 persen. Berarti semakin meningkat upah tenaga kerja maka semakin menurun pendapatan usahatani padi.

Dampak keanggotaan kelompok lumbung pangan tidak berpengaruh secara signifikan terhadap tingkat pendapatan usahatani padi. Hal ini dapat terjadi karena seluruh kegiatan kelompok lumbung pangan masih sepenuhnya mengandalkan bantuan sosial pemerintah atau bansos, sehingga kemampuannya masih relatif terbatas untuk melayani dan menanggulangi keseluruhan anggota kelompoknya. Di sisi lain, peran serta atau partisipasi aktif anggota dalam kegiatan kelompok lumbung pangan masih terbatas. Menurut Mardiyati (2016) faktorfaktor yang mempengaruhi partisipasi petani dalam aktivitas kelembagaan lumbung pangan adalah luas lahan, jarak lumbung pangan, dan tingkat persepsi petani terhadap aktivitas lumbung pangan.

\section{KESIMPULAN DAN SARAN}

1. Pendapatan usahatani padi yang diperoleh petani anggota kelompok lumbung pangan sebesar Rp 9.386.227,00 sedangkan pendapatan yang diperoleh petani nonanggota lumbung pangan sebesar Rp 9.175.144,00.

2. Perbedaan tingkat produksi, penerimaan, dan pendapatan usahatani padi antara petani anggota dan non-anggota kelompok lumbung pangan berdasarkan $t$ test terbukti tidak berbeda nyata.

3. Faktor-faktor yang berpengaruh signifikan terhadap tingkat pendapatan usahatani padi adalah luas lahan, harga benih padi, harga pestisida, dan upah tenaga kerja.

4. Dampak keanggotaan kelompok lumbung pangan ternyata tidak berpengaruh signifikan terhadap tingkat pendapatan usahatani padi.

\section{SARAN}

1. Kemajuan kelompok lumbung pangan seharusnya selalu diupayakan pengembangannya secara lebih mandiri dalam berbagai kegiatan sehingga tidak hanya mengandalkan bansos dari pemerintah.

2. Perlu upaya sosialisasi yang lebih meluas tentang pentingnya fungsi dan peran kelompok lumbung pangan bagi masyarakat perdesaan, sehingga akan berdampak positif bagi pengembangan berbagai usahatani, terutama usahatani padi. 


\section{DAFTAR PUSTAKA}

Anonim. 2015. Pedoman Pengembangan Lumbung Pangan Masyarakat Tahun 2015. Kementerian Pertanian Republik Indonesia.

Mardiyati, S. 2014. Pengaruh Kinerja Lumbung Pangan terhadap Harga, Pendapatan, dan Kemandirian Pangan Rumah Tangga Tani di Daerah Istimewa Yogyakarta. Disertasi. Program Pascasarjana, Fakultas Pertanian, Universitas Gadjah Mada. Yogyakarta

Mardiyati, S dan Molla, S. 2016. Partisipasi Petani dalam Revitalisasi Kelembagaan Lumbung Pangan Masyarakat sebagai Penguatan Kemandirian Pangan Lokal di Kabupaten Takalar. Dalam Prosiding Seminar Nasional Hasil Penelitian Pertanian: Peningkatan Sinergi dan Inovasi Teknologi Untuk Kedaulatan Pangan. Fakultas Pertanian Universitas Gadjah Mada. Yogyakarta.
Soekartawi. 2006. Analisis Usahatani. UI Press. Jakarta.

Sugiyono. 2008. Metode Penelitian Kuantitatif, Kualitatif, dan $R \& D$. Penerbit Alfabeta. Bandung.

Suharyanto, Mulyo, J.H., Darwanto, D.H., dan Widodo, S. 2014. Analisis Ketahanan Pangan Rumahtangga Petani (Modifikasi Metode Jonsson and Toole dengan Pendekatan Analisis Ordered Logistic). Dalam Prosiding Seminar Nasional Hasil-Hasil Penelitian Pertanian: Pengembangan dan Pemanfaatan lmu Pengetahuan dan Teknologi untuk Kedaulatan Pangan. Fakultas Pertanian Universitas Gadjah Mada. Yogyakarta. 
